\title{
Physiological and Agronomic Characterisation of Six Cassava Clones (Manihot esculenta Crantz)
}

\section{Caracterización Fisiológica y Agronómica de Seis Clones de Yuca (Manihot esculenta Crantz)}

\author{
Eguiluz, A. $\left({ }^{1}\right)^{*}$; Pinedo, R. $\left({ }^{1}\right)$; Figueroa, C. $\left({ }^{1}\right)$ \\ *Corresponding author: aeguiluz@lamolina.edu.pe
}

\begin{abstract}
To evaluate the behaviour of cassava clones (Manihot esculenta Crantz), the physiological quality of the propagation material was assessed, and an agronomic characterisation was conducted; this was essential for the generation of information on the clones' productive potential. The trial was conducted in the experimental field of the Roots and Tubers programme (PIPS-RT) of the National Agrarian University-La Molina. Following a completely randomised block design with four replications, clones from the PIPS-RT were evaluated. Variables were assessed to determine the clones' physiological quality in terms of the number of viable stakes, normal seedlings, abnormal seedlings and percentage of stake survival. The agronomic characteristics evaluated were plant height, stem diameter and yield. The Morocha clone had the highest percentage of viable stakes and normal seedlings, i.e. $80.95 \%$ and $73.81 \%$, respectively. The highest yield was also produced by the Morocha clones $(13 \mathrm{t} / \mathrm{ha})$ followed by the Donoso $2(7.20 \mathrm{t} / \mathrm{ha})$ and Blanca Cajamarca (6.80 t/ha) varieties.
\end{abstract}

Keywords: characterisation, yield, seedling, productive potential

\section{Resumen}

Con la finalidad de evaluar el comportamiento seis clones de yuca (Manihot esculenta Crantz), se realizaron evaluaciones relacionadas a la calidad fisiológica del material de propagación y caracterización agronómica, requerida para generar información sobre la potencialidad de los clones. El ensayo se llevó a cabo en el campo experimental de Programa de Raíces y Tuberosas de la UNALM (PIPS-RT), bajo un diseño de bloques completamente al azar con cuatro repeticiones, se evaluaron clones provenientes de una colecta del PIPS-RT. Las variables en estudio para determinar la calidad fisiológica de los clones fueron número de estacas viables, plántulas normales, plántulas anormales y el porcentaje de supervivencia de estacas; mientras que para características agronómicas fueron altura de la planta, diámetro del tallo y rendimiento. El clon Morocha presentó el mayor porcentaje de estacas viables y plántulas normales con $80.95 \%$ y $73.81 \%$ respectivamente. Asimismo, el mayor rendimiento se halló con los clones Morocha (13 t/ha) seguido de Donoso 2 (7.20 t/ha) y Blanca Cajamarca (6.80 t/ha).

Palabras clave: caracterización, rendimiento, plántula, potencial productivo

\section{Introduction}

Currently, plant genetic resources are essential in sustainable agricultural production, and their conservation and effective use are fundamental for global food security (Reveles \& Velasquez, 2017). Therefore, a continuous flow of improved crops and varieties adapted to particular local conditions will be necessary (FAO, 2017). There is a positive outlook for production in countries with food diversification programmes or in those that intend to limit the imports of staple foods, especially wheat and rice (FAO, 2017).
Cassava (Manihot esculenta Crantz) cultivation has high economic and nutritional importance. Globally, it is considered as the fourth most important commodity following rice, wheat and corn (Mejía, Elias-Da-Silva, Mejía, \& García-Dávila, 2015). In addition to direct consumption, it is also used as a raw material in the preparation of concentrates for animals, paper and textiles, biofuels and starch for the food and pharmaceutical industries (Beovides et al., 2014; FAO, 2013).

Cassava is a species of the Euphorbiaceae family, which is distributed in tropical and subtropical areas of the 
world with the greatest proportion in Mexico and Brazil (FAO, 2013). The morphological and genetic diversity of this species has been characterised in terms of cultivated varieties with around 7000 varieties distributed worldwide (INTA, 2016). These are mostly morphotypes and are maintained by traditional farmers.

Cassava is native to the American tropics (INTA, 2016). There is a great diversity of ecotypes, which must be collected, protected, characterised and evaluated because they are the basis for the development of improved varieties to ensure the production of food and other requirements (Agre et al., 2015; FAO; 2017; Reveles \& Velásquez, 2017).

In Peru, cassava cultivation provides one of the main energy sources and is part of the subsistence strategies of families. A large number of local varieties are distinguished, identified by farmers by a common or singular name based on morphological characteristics, place of origin or names of people who introduced the variety to the community (INTA, 2016).

Morphological characteristics are used to study genetic variability, to identify plants and to conserve genetic resources (FAO, 2013; INTA, 2016). Therefore, characterisation is the first step to improving crops and conservation programmes. In addition to the influence of the particular genotype, the characteristics are strongly influenced by the environment, such as the amount of rainfall, soil fertility and damage due to pests and diseases (INTA, 2016). In areas of prolonged drought (which is the major constraint to the success of food crops), cassava (Manihot esculenta Crantz) is a viable crop choice. However, despite this crop's rusticity, it is affected by extreme environments (León et al., 2014).

The vigour of the cassava stakes as a means of propagation is dependent on genetic, physical, and physiological characteristics (Teichert, Amaral, \& Meneghello, 2012). Therefore, the viability level of the stakes and their ability to thrive once the roots and leaves have formed are an expression of the clone's physiological qualities. Under this consideration, the potential for yield, stability and pest resistance along with the physiological quality of the mother plant should be taken into account in the selection of stakes. An otherwise perfect genotype cannot express its full potential if a physiologically deteriorated propagation material is used (CLAYUCA, 2006).

Regarding the agronomic character of yield per unit area and with particular respect to the performance of tuberous roots, Peso and Vasquez (1995) believe that not only is performance the most important characteristic, but it also constitutes a clonal characteristic, although it is influenced by environmental and cultural factors. Currently, manuals are available for cassava characterisation, such as the descriptors published by the International Board for Plant Genetic Resources in 1983, the Brazilian Company of Agricultural Research in 1998 and the International Institute of Tropical Agriculture in 1998.

Most cassava research prioritises Peruvian jungle agroecosystems and is focused on studies with dualpurpose clones (roots and fodder); however, in this paper, the research focuses on the identification of promising high yield clones for coastal conditions.

According to MINAGRI (2018), the departments of Amazonas, Junín, Loreto, San Martín and Ucayali account for more than $70 \%$ of Peruvian cassava production. However, the highest yields are obtained in the coastal departments of Lima (34.5 t/ha), Arequipa (15.04 t/ha), Ancash (20.3 t/ha) and Ica (25 t/ha) compared with the national yield of $12 \mathrm{t} / \mathrm{ha}$ in recent years.

Cassava can withstand prolonged periods of drought in which most other food plants perish (CLAYUCA, 2006). This makes it very useful in regions where annual rainfall is low or where there is an irregular seasonal distribution of rainfall (Grace, 1977). In addition, it has enormous potential for productivity in poor soils owing to its plasticity and tolerance against pests and diseases (FAO, 2013; INTA, 2016).

Therefore, the main objective of this research was to evaluate the physiological and agronomical performance of cassava clones in the National Agrarian University-La Molina (UNALM) Roots and Tubers programme (PIPSRT) with high yield potential and quality root production.

\section{Materials and Methods}

The study was conducted between October 2016 and October 2017 in the PIPS-RT of the UNALM located in La Molina, Lima, at $241 \mathrm{~m}$ above sea level (the geographic coordinates are $12^{\circ} 05.099$ 'S, 76 $56.974^{\prime}$ SO). The plant material under investigation is presented in Table 1. The material was selected due to the use of the main clones in the Peruvian coastal area.

The characteristics of the experimental area were as follows:

Table 1. Code, name, origin and vegetative period of the genetic material used in the experiment.

\begin{tabular}{llll}
\hline Code & Name & Origin & Vegetative period (months) \\
\hline T1 & $\begin{array}{l}\text { Rosado } \\
\text { Cañete } \\
\text { T2 }\end{array}$ & Cañete & 9-10 months \\
Donoso 1 & $\begin{array}{l}\text { Lima. } \\
\text { PIPS-RT }\end{array}$ & Late, older than 12 months \\
T3 & Donoso 2 & $\begin{array}{l}\text { Lima. } \\
\text { PIPS-RT }\end{array}$ & Late, older than 12 months \\
T4 & Morocha & $\begin{array}{l}\text { Lima. } \\
\text { PIPS-RT }\end{array}$ & Semi-early 7-8 months \\
T5 & $\begin{array}{l}\text { Negra } \\
\text { Mochera } \\
\text { Blanca } \\
\text { Cajamarca }\end{array}$ & $\begin{array}{l}\text { PIPS-RT } \\
\text { Cajamarca }\end{array}$ & Semi-early 9-10 months \\
T6 & Semi-early 9-10 months. \\
\hline
\end{tabular}


Groove length $(6 \mathrm{~m})$, distance between rows $(1.2 \mathrm{~m})$, distance between strokes $(1 \mathrm{~m})$, number of stokes by groove (5), number of stakes per stroke (1), number of grooves by plot (4), plot area $\left(28.8 \mathrm{~m}^{2}\right)$, street width $(1.50$ $\mathrm{m})$ and total experimental area $\left(705.6 \mathrm{~m}^{2}\right)$.

The genetic material under study is part of the collection of cassava varieties and morphotypes of the PIPS-RT of the UNALM. Through previous characterisation work conducted by the PIPS-RT, the best-performing material clones were screened in terms of yield, physiological quality of stakes for propagation in crop fields and resistance to biotic and adverse abiotic factors. The selected clones were characterised by the presentation in the roots of the following pulp colours: Rosé cañete (yellow group 8D), Donoso 1 (white group 155D), Donoso 2 (white group 155D), Morocha (yellow-orange group 19C), Black Mochera (white group 155D) and Blanca Cajamarca (white group 155D) (Table 1).

\section{Agronomic husbandry}

The vegetative propagation used fresh stakes from mature plants (Villagómez \& Rodríguez, 1993). The stake diameter was related to the diameters of the central cylinder and the stem; the stakes had a diameter between 1 and $1.5 \mathrm{~cm}$ (INIA, 2014) and a length of $8-10 \mathrm{~cm}$, and to ensure rooting, they had $3-5$ buds located in the nodes. The stake was inclined for planting; this encouraged horizontal root development to prevent damage while developing.

Hilling was conducted 4 months after planting so that the reserve roots could develop a favourable shape. At the time of hilling, approximately $50 \mathrm{~g} /$ stroke of fertiliser was applied at a dose of 20-20-20 NPK, according to the recommendation of León et al. (2014). Cassava is recognised for its high rusticity and tolerance to biotic and abiotic stresses, including low soil fertility (Alzate, 2009; Jaramillo, 2002). Therefore, it was considered appropriate to use a low level of fertilisation to observe the expression of the clones under these conditions.

Weeding was performed manually according to requirements. The first weeding took place 30 days after planting. A gravity irrigation system was used depending on the availability of water and the crop's requirements. In the first stage, the crops were watered twice a week and from the third month once a week or depending on the conditions. The first irrigation was at approximately 15 days. Cassava is not very demanding on soil moisture content, but a prolonged moisture deficit has a negative impact on growth and yield (INTA, 2016). Although cassava is tolerant to pest attack compared with other crops, its production does not occur in critical periods; therefore, evaluations of pests and diseases were conducted once a week with remedial applications made according to the incidence.

After 9 months, the storage root was harvested. One of the last activities in cassava production consists of collecting the useful part of the plant, in this case the reserve root. The optimal degree of humidity to facilitate the extraction of the tuberous root (while avoiding tearing the bark) was taken into consideration during this stage (INTA, 2016). Some characteristics indicative of maturity were also observed, such as the fall of the basal leaves and the cracking of the soil at the base of the plant stem. The crop was harvested manually depending on the maturity of the clone, and prior to harvesting, the crop was watered.

\section{Evaluation variables}

\section{Physiological quality variables}

The percentage of stakes installed in the experiment was evaluated and then analysed. The number of viable stakes, number of normal seedlings and stake survival percentage of the six clones were evaluated. The criteria for the evaluation of any abnormal plants were size, colour and leaf shape, as well as deformations compared with normally developed plants in each block according to the cassava descriptor (Biodiversity International, 2011). Additionally, some evaluations that are not included in the descriptors were used.

\section{Agronomic variables}

The variables that were evaluated were plant height, stem diameter and yield.

The physiological and agronomic variables used in the evaluation of the experiment allowed the best clones to be defined. Noerwijatia and Budionob (2015) applied stress tolerance and susceptibility indices and average productivity and performance stability indices as selection criteria for identifying the best clone at different heights.

\section{Data Analysis}

An analysis of variance was conducted using InfoStat (2017 version) statistical software. Duncan's multiple range test was employed to compare the means of the treatments at a significance level of $5 \%$.

\section{Results}

\section{Seedling emergence}

In the analysis of variance, no significant statistical differences were found in the variables for the treatments for the viable stakes and normal seedlings (Table 2).

Twenty-two days after the start of the experiment, an average of $63 \%$ sprouting had occurred. The results indicate that $14 \%$ of the plants were abnormal. By comparing the mean variables of the viable stakes via Duncan's multiple range test, the best response was obtained from the Morocha clone, which had 73.81\% viable stakes when forming rootlets and primary leaves; the lowest percentage of viable stakes was with the Donoso 
Table 2. Analysis of variance of physiological variables in the percentage of viable stakes and normal seedlings.

\begin{tabular}{|c|c|c|c|}
\hline \multirow{2}{*}{$\begin{array}{l}\text { Sources of } \\
\text { variation }\end{array}$} & \multicolumn{3}{|c|}{ Mean squares } \\
\hline & GL & $\begin{array}{c}\text { Viable sprouting } \\
(\%)\end{array}$ & $\begin{array}{c}\text { Normal } \\
\text { plantlets (\%) }\end{array}$ \\
\hline Treatment & 5 & 188.21 & 162.28 \\
\hline Block & 2 & 79.37 & 121.88 \\
\hline Error & 10 & 70.01 & 62.36 \\
\hline Total & 17 & & \\
\hline $\mathrm{CV} \%$ & & 11.28 & 12.1 \\
\hline
\end{tabular}

$* 0.05$ probability significance, $* * 0.01$ probability significance

Table 3. Duncan's multiple range test for viable stakes (\%) and normal seedling $(\%)$

\begin{tabular}{llc}
\hline Clones & Viable sprouting & Normal plantlets \\
\hline Morocha & $80.95 \mathrm{~A}$ & $73.81 \mathrm{~A}$ \\
Blanca Cajamarca & $79.76 \mathrm{~A}$ & $70.24 \mathrm{~A}$ \\
Donoso 1 & $77.38 \mathrm{~A}$ & $66.67 \mathrm{~A}$ \\
Rosado Cañete & $76.19 \mathrm{~A}$ & $65.48 \mathrm{~A}$ \\
Negra Mochera & $71.43 \mathrm{AB}$ & $63.10 \mathrm{AB}$ \\
Donoso 2 & $59.52 \mathrm{~B}$ & $52.38 \mathrm{~B}$ \\
\hline
\end{tabular}

Note: Different letters indicate statistically significant differences, according to Duncan's multiple range test $(p \leq 0.05)$.

Table 4. Analysis of variance for yield ( $\mathrm{t} / \mathrm{ha})$, plant height $(\mathrm{cm})$ and stem diameter $(\mathrm{cm})$

\begin{tabular}{lclll}
\hline & & \multicolumn{3}{c}{ Means squares } \\
\cline { 3 - 5 } F.V. & gl & Yield & Plant height & $\begin{array}{l}\text { Stem } \\
\text { diameter }\end{array}$ \\
\hline Block & 2 & 1.694 & 279.243 & 0.024 \\
Treatment & 5 & $25.786^{*}$ & 636.23 & $0.302 * *$ \\
Error & 10 & 5.381 & 1209.315 & 0.025 \\
Total & 17 & & & \\
\hline CV \% & & 32.019 & 13.095 & 5.661 \\
\hline
\end{tabular}

$* 0.05$ probability significance, $* * 0.01$ probability significance.

Table 5. Duncan's multiple range test for yield, plant height and stem diameter

\begin{tabular}{llllll}
\hline \multicolumn{1}{c}{$\mathrm{T}$} & $\begin{array}{l}\text { Yield } \\
\text { t/ha }\end{array}$ & $\mathrm{T}$ & $\begin{array}{l}\text { Plant } \\
\text { height } \\
(\mathrm{cm})\end{array}$ & $\mathrm{T}$ & $\begin{array}{l}\text { Stem } \\
\text { diameter } \\
(\mathrm{cm})\end{array}$ \\
\hline $\mathrm{T} 4$ & $13.00 \mathrm{~A}$ & $\mathrm{~T} 5$ & $282.500 \mathrm{~A}$ & $\mathrm{~T} 5$ & $3.233 \mathrm{~A}$ \\
$\mathrm{~T} 3$ & $7.20 \mathrm{AB}$ & $\mathrm{T} 4$ & $278.967 \mathrm{~A}$ & $\mathrm{~T} 3$ & $3.033 \mathrm{AB}$ \\
$\mathrm{T} 6$ & $6.80 \mathrm{AB}$ & $\mathrm{T} 3$ & $263.993 \mathrm{~A}$ & $\mathrm{~T} 1$ & $2.967 \mathrm{ABC}$ \\
$\mathrm{T} 2$ & $5.93 \mathrm{~B}$ & $\mathrm{~T} 6$ & $263.433 \mathrm{~A}$ & $\mathrm{~T} 4$ & $2.633 \mathrm{~B} \mathrm{CD}$ \\
$\mathrm{T} 5$ & 5.50 B & $\mathrm{T} 1$ & $263.067 \mathrm{~A}$ & $\mathrm{~T} 6$ & $2.533 \mathrm{CD}$ \\
$\mathrm{T} 1$ & $5.03 \mathrm{~B}$ & $\mathrm{~T} 2$ & $241.467 \mathrm{~A}$ & $\mathrm{~T} 2$ & $2.433 \mathrm{D}$ \\
\hline
\end{tabular}

Means with a common letter are not significantly different $(\mathrm{p}>0.05)$ $\mathrm{T}=$ Treatment

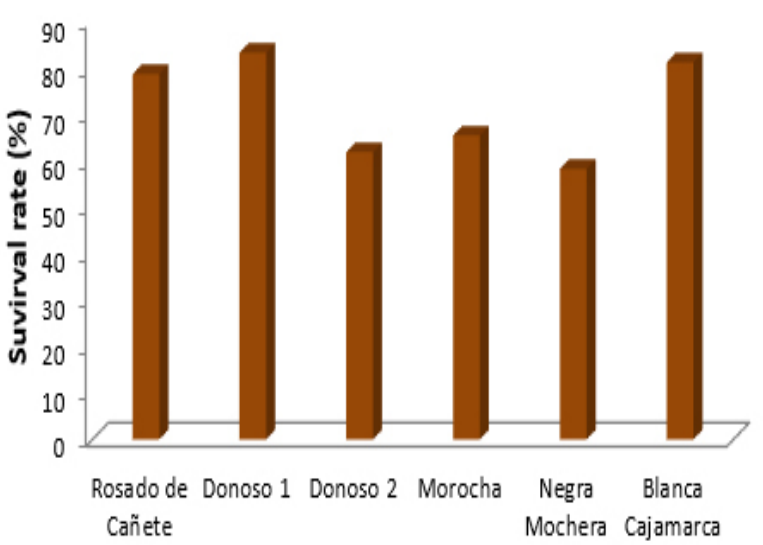

Cassava clones

Figure 1. Percentage of stake survival of cassava clones in the final field

2 clone at just 52.38\%. The Morocha, Blanca Cajamarca, Donoso 1 and Rosado Cañete clones were statistically identical; however, they are statistically different of the Negra Mochera and Donoso 2 clones (Table 3).

Of a total of 168 stakes planted, $71.4 \%$ exhibited good development and reached a height of between 70 and $100 \mathrm{~cm}$. Figure 1 shows that the percentage of plants in vegetative growth was between $58.2 \%$ in the Negra Mochera genotype and $83.2 \%$ in the Donoso 1 genotype.

The analysis of variance for yield reveals significant differences between the treatments, whereas for plant height, no significant statistical differences were found. However, highly significant statistical differences were found for stem thickness. The coefficients of variation for the three variables were 32,019, 13,095 and 5,661, respectively (Table 4).

Duncan's multiple range test for the comparison of means for yield (Table 5). There were significant differences between the clones; the Morocha clone produced a higher average yield that reached $13.00 \mathrm{t} / \mathrm{ha}$, which was superior to the others. Clones T3 and T6 were not significantly different with yields of 7.20 and 6.80 but were better with T2, T5 and T1 treatments. Treatments T2, T5 and T1 with 5.93, 5.50 y 5.03 t/ha respectably, did not result in significant differences, but they were less than other treatments.

The highest plant height was demonstrated with T5 followed by T4 and T3; however, they were not statistically different from the other treatments. With respect to stem diameter, the highest mean was obtained from the T5 treatment followed by $\mathrm{T} 3$ and $\mathrm{T} 1$. This was statistically different from the other treatments.

At 63 days after sowing (dds), a 60\% yield was achieved along with the emergence of stems. In this regard, the INTA (2016) mentions that this stage includes the time from sowing until 60 dds. 


\section{Discussion}

Cassava stakes were used as a means of propagation due to the species' allogamous condition and its heterozygous genetic constitution (Jaramillo, 2002). A 60\% yield and the emergence of stems were achieved at 63 dds. According to the INTA (2016), this stage includes the time from sowing until $60 \mathrm{dds}$; the stakes when sprouting first form roots (5-7 dds), and then the stems and leaves develop. Cassava tolerates a wide temperature range; however, this factor may affect sprouting (INTA, 2016). Stakes cut from healthy stems that are free of pests and diseases have higher sprouting and root production rates (FAO, 2013). The tangible result of the physiological quality of the stake is in its ability to sprout and produce a vigorous plant (CLAYUCA, 2006).

In cassava, the height and stem diameter are important characteristics because they are the media used for vegetative multiplication. In the experiment, height varied from 241.67 to $282.50 \mathrm{~m}$, and clone T4 achieved the best expression in this variable. Cassava is a perennial shrub with a sympodial branching habit whose height can range from 3 to $5 \mathrm{~m}$ (the average is $3 \mathrm{~m}$ ). It is characterised by the sprouting of the stakes, which first form roots (5-7 dds) before the stems and leaves develop.

The Morocha clone (T4) achieved the best yield (13 $\mathrm{t} / \mathrm{ha}$ ). It should be noted that the national average yield from the Morocha clone does not exceed $12 \mathrm{t} / \mathrm{ha}$, which could prove interesting for future work. In this regard, when evaluating the agronomic behaviour of eight clones, Peso and Vasquez (1995) found a yield that varied between 13.85 and $26.76 \mathrm{t} / \mathrm{ha}$, whereas Perdomo et al. (2008) identified potential root yields for fresh consumption of between 14.00 and $18.00 \mathrm{t} / \mathrm{ha}$. The best-performing clone may have a promising future since it is within the global average of performance. According to FAO (2017), the average global yield has increased by almost $1.8 \%$ per year during the last decade, reaching $12.8 \mathrm{t} / \mathrm{ha}$.

Regarding plant height in the test, clones $\mathrm{T} 4$ and T5 reached 278.97-282.50 cm, which was a better performance than the other clones; however, they were not statistically different. When evaluating plant height, León et al. (2014) revealed significant differences $(\mathrm{p}<$ $0.05)$ among clones $(2.17-2.62 \mathrm{~m})$. The cassava shrub can measure 1.5-4.0 $\mathrm{m}$ high (INTA, 2016); however, under the conditions in Loreto, the cassava plant reaches $2-3 \mathrm{~m}$ in height (Inga \& López, 2001).

\section{Conclusions}

The Morocha clone demonstrated the highest percentage of sprouting behaviour and normal plantlets at $80.95 \%$ and $73.81 \%$, respectively. The highest yield was also found with the Morocha clone (13 t/ha) followed by the Donoso 2 $(7.20 \mathrm{t} / \mathrm{ha})$ and the Blanca Cajamarca $(6.80 \mathrm{t} / \mathrm{ha})$ varieties.
Clones T4, T5 and T6 have promising potential for future improvement or in propagation plans for commercial purposes because they did not exhibit brittle roots, and they responded with yields above the national average under conditions of low fertilisation. These results could be useful in the implementation of sustainable agronomic management of cassava on the Peruvian coast.

\section{References}

Agre, A.P., Dansi, A., Rabbi, I.Y., Battachargee, R., Dansi, M., Melaku, G., Augusto, B., Sanni, A., Akouegninou, A., \& Akpagana, K. (2015). Agromorphological Characterization of Elite Cassava (Manihot esculenta Crantz) Cultivars Collected in Benin. International Journal of Current Research in Biosciences and Plant Biology, 2(2): 1-14. Retrieved from https://core.ac.uk/download/ pdf/132668705.pdf

Alzate, A. (2009). Variabilidad genética y grado de adopción de la yuca (Manihot esculenta Crantz) cultivada por pequeños agricultores de la costa Atlántica Colombiana. Universidad Nacional de Colombia Facultad de Ciencias Agropecuarias, Palmira - Colombia. 63 p.

Beovides, Y., Milián, M., Coto, O., Rayas, A., Basail, M., Santos A., López, J., Medero, V., Cruz, J., Ruíz, E., \& Rodríguez, D. (2014). Caracterización morfológica y agronómica de cultivares cubanos de yuca (Manihot esculenta Crantz). Cultivos Tropicales, 35(2), 43-50. Retrieved from http:// www.redalyc.org/articulo.oa?id=193230070006

CLAYUCA (Consorcio Latinoamericano y del Caribe de Apoyo a la Investigación y al Desarrollo de la Yuca-Clayuca). (2006). Aspecto tecnológicos sobre producción de yuca. CIAT. Colombia. 28 p.

FAO (Organización de las Naciones Unidas para la Alimentación y la Agricultura). (2013). Ahorrar para crecer: La Yuca, Guía para la intensificación sostenible de su cultivo. Retrieved from http:// www.fao.org/ag/save-and-grow/cassava/pdf/FAOYuca.pdf

FAO (Organización de las Naciones Unidas para la Alimentación y la Agricultura). (2017). Perspectivas alimentarias, Resumen de mercado octubre de 2016. Roma-Italia. p. 7. Retrieved from $\underline{\text { http://www.fao.org/publications/card/es/ }}$ c/1bbcf185-eff5-4647-9379-97799849d912/

Grace, M.R. (1977). Colección FAO: Producción y protección vegetal. $\mathrm{N}^{\circ} 3$. Elaboración de la Yuca. Roma, Italia. p. 11.

Inga, H., \& López, J. (2001). diversidad de yuca (Manihot 
esculenta crantz) en Jenaro Herrera, Loreto-Perú. Instituto de Investigaciones de la Amazonía Peruana (IIAP), Loreto, Perú. 47 p. Retrieved from http:// www.iiap.org.pe/upload/Publicacion/ST028.pdf

INIA (Instituto Nacional de Investigación Agraria). (2014). Tecnología de Producción de Yuca: Selección, preparación y desinfección de estacas de yuca. Hoja divulgativa $\mathrm{N}^{\circ}$ 16.Iquitos. Retrieved from https:// www.inia.gob.pe/

INTA (Instituto Nacional de Innovación y Transferencia en Tecnología Agropecuaria). (2016). Cultivo de yuca (Manihot esculenta Crantz) en Costa Rica. San José, C.R. 87 p.

León, R., Pérez, M., Gutiérrez, M., Rodríguez, A., Fuenmayor, F., \& Marín, C. (2014). Caracterización ecofisiológica de cuatro clones de yuca del banco de germoplasma del INIA-CENIAP. Agronomía tropical, 64, 97-105

Mejía J., Elias-Da-Silva R., Mejía K., \& García-Dávila C. (2015). Caracterización morfológica y genética de etnovariedades de la yuca Manihot esculenta Cratnz, en seis localidades de la cuenca baja del río Ucayali-Perú. Folia Amazónica, 24, 71-82.

MINAGRI (Ministerio de Agricultura y Riego). (2018). Boletín estadístico mensual: El agro en cifras noviembre 2018 (online). Sistema Integrado de Estadística Agraria (SIEA). Retrieved from http://siea.minagri.gob.pe/siea/?q=noticias/ boletin-estadistico-mensual-el-agro-en-cifrasnoviembre-2018

Noerwijatia, K., \& Budionob, R. (2015). Yield and yield components evaluation of Cassava_(Manihot esculenta Crantz) clones in different altitudes. Energy Procedia, 155-161.

Jaramillo, G.. (2002). Recursos genéticos de Manihot en el Centro Internacional de Agricultura Tropical (CIAT). In B. Ospina \& H. Ceballos (Eds.), La Yuca en el tercer milenio: sistemas modernos de producción, procesamiento, utilización y comercialización (pp. 271-294). Cali, Colombia: Centro Internacional de Agricultura Tropical (CIAT). https://hdl.handle.net/10568/54117

Peso, N., \& Vásquez, W. (1995). Comparativo de rendimiento de ocho clones de yuca (Manihot esculenta, Crantz). Folia Amazónica, 7 (1-2)-1995

Reveles, L.R. \& Velásquez, R. (2017). Patrimonio fitogenético: Banco de germoplasma de semillas ortodoxas del Campo Experimental Zacatecas. Folleto Técnico Núm 81. Campo Experimental Zacatecas. CIRNOC-INIFAP, 44 páginas.

Teichert, S., Amaral, F., \& Meneghello, G.E. (2012).
Sementes: Fundamentos científicos e tecnológicos. Tercera edición. Pelotas R.S. Brasil. 527 p.

Villagómez V. \& Rodríguez G. (1993). El Cultivo de la Yuca (Manihot esculenta). Ediciones UNALM. Impresión Comercial Grafica Jara S.R.L. LimaPerú. p. 5, 30, 36, 42, 66. 